\title{
Concentrations, sources and geochemistry of airborne particulate matter at a major European airport
}

\author{
Fulvio Amato, ${ }^{* a}$ Teresa Moreno, ${ }^{a}$ Marco Pandolfi, ${ }^{a}$ Xavier Querol, ${ }^{a}$ Andrés Alastuey, ${ }^{a}$ Ana Delgado, \\ Manuel Pedrero ${ }^{b}$ and Nuria $\operatorname{Cots}^{c}$
}

\author{
Received 2nd December 2009, Accepted 15th January 2010 \\ First published as an Advance Article on the web 15th February 2010 \\ DOI: $10.1039 / b 925439 k$
}

Monitoring of aerosol particle concentrations $\left(\mathrm{PM}_{10}, \mathrm{PM}_{2.5}, \mathrm{PM}_{1}\right)$ and chemical analysis $\left(\mathrm{PM}_{10}\right)$ was undertaken at a major European airport (El Prat, Barcelona) for a whole month during autumn 2007. Concentrations of airborne PM at the airport were close to those at road traffic hotspots in the nearby Barcelona city, with means measuring $48 \mu \mathrm{g} \mathrm{PM}_{10} / \mathrm{m}^{3}, 21 \mu \mathrm{g} \mathrm{PM}_{2.5} / \mathrm{m}^{3}$ and $17 \mu \mathrm{g} \mathrm{PM}_{1} / \mathrm{m}^{3}$.

Meteorological controls on PM at El Prat are identified as cleansing daytime sea breezes with abundant coarse salt particles, alternating with nocturnal land-sourced winds which channel air polluted by industry and traffic $\left(\mathrm{PM}_{1} / \mathrm{PM}_{10}\right.$ ratios $\left.>0.5\right) \mathrm{SE}$ down the Llobregat Valley. Chemical analyses of the $\mathrm{PM}_{10}$ samples show that crustal PM is dominant ( $38 \%$ of $\left.\mathrm{PM}_{10}\right)$, followed by total carbon $(\mathrm{OC}+\mathrm{EC}$, $25 \%$ ), secondary inorganic aerosols (SIA, 20\%), and sea salt (6\%). Local construction work for a new airport terminal was an important contributor to $\mathrm{PM}_{10}$ crustal levels. Source apportionment modelling PCA-MLRA identifies five factors: industrial/traffic, crustal, sea salt, SIA, and $\mathrm{K}^{+}$likely derived from agricultural biomass burning. Whereas most of the atmospheric contamination concerning ambient air $\mathrm{PM}_{10}$ levels at El Prat is not attributable directly to aircraft movement, levels of carbon are unusually high (especially organic carbon), as are metals possibly sourced from tyre detritus/smoke in runway dust $(\mathrm{Ba}, \mathrm{Zn}, \mathrm{Mo})$ and from brake dust in ambient $\mathrm{PM}_{10}(\mathrm{Cu}, \mathrm{Sb})$, especially when the airport is at its most busy. We identify microflakes of aluminous alloys in ambient $\mathrm{PM}_{10}$ filters derived from corroded fuselage and wings as an unequivocal and highly distinctive tracer for aircraft movement.

\section{Introduction}

Given the many published studies on urban air pollution, there are surprisingly few that specifically deal with airports serving major cities, despite the fact that such travel hubs form atmospheric contamination hotspots visited by tens of millions of people annually. Air traffic and the ground services that support it, have grown enormously in recent years, increasing by around $50 \%$ in the 1990 s alone, ${ }^{1}$ and many airports are currently

anstitute of Environmental Assessment and Water Research (IDAEA), Spanish National Research Council (CSIC), clJordi Girona 18-26, 08034 Barcelona, Spain. E-mail: fulvio.amato@idaea.csic.es

${ }^{b}$ Spanish Airports and Air Navigation (AENA), Dept. of Environment, Barcelona, Spain

${ }^{c}$ Generalitat de Catalunya, Departament de Medi Ambient i Habitatge, Av. Diagonal, 523-525 Barcelona, Spain enacting plans to double or even treble their passenger throughput during the early part of this century. One result of such unprecedented expansion has been a notable increase in local gaseous emissions linked to airports, notably as volatile organic compounds (VOCs) and $\mathrm{NO}_{x},{ }^{2}$ as well as a discernable influence on broader atmospheric environmental issues such as damage to the ozone layer, anthropogenic greenhouse gas levels, and aerosol radiative balance..$^{3-9}$

Publications dealing with local increases in air contamination attributable to airports have tended to focus on specific pollutants, such as $\mathrm{SO}_{2}$ and $\mathrm{CO}$ (Hong Kong and Los Angeles), ${ }^{10} \mathrm{PM}_{2.5}$ and $\mathrm{O}_{3}$ (Atlanta), ${ }^{11}$ or airborne metals (Chicago). ${ }^{12}$ In a recent study at the small Santa Monica Airport in California, Hu et al. ${ }^{13}$ found that aircraft operations resulted in average ultrafine particle concentrations elevated over background levels by factors of 10 and 2.5 at 100 and $660 \mathrm{~m}$, respectively, at large residential areas

\section{Environmental impact}

Given the numerous studies on urban PM pollution, there is surprisingly a dearth of knowledge on PM pollution at major airports, despite the fact that these hotspots are visited by tens of millions of people annually. This study provides information about the controlling influences on levels and chemical composition of $\mathrm{PM}_{10}$ at the Barcelona airport. Results suggest that most of the PM measured inside the airport is not attributable to aircraft movements, although there are exceptions: organic carbon and some metals may owe their origin at least in part to aircraft operations such as take-off, tyre abrasion/smoke during aircraft landing. Evidence for uniquely aircraft-generated particles comes from the discovery of aluminous microflakes derived from airframe corrosion, for the first time identified in ambient air, but presumably commonplace around all airports. 
downwind of the airport, revealing the potential health implications for persons living near general aviation airports.

In this paper we present the results of a more integrated PM study involving the measurement and analysis of particulate matter pollutants at Barcelona (El Prat) airport on the Mediterranean coast of NE Spain, examining the controlling influences on levels of $\mathrm{PM}_{10}, \mathrm{PM}_{2.5}, \mathrm{PM}_{1}$ and $\mathrm{PM}_{10}$ chemical composition during a field monitoring campaign in late 2007 . We also use a new method of sampling the $\mathrm{PM}_{10}$ fraction of runway dust, ${ }^{14}$ in this case applied to airport runways, to investigate the presence of fine metalliferous particles derived from aircraft fuselage and tyre wear.

El Prat is in many ways highly typical of many of the larger world airports. It lies close to sea level and is connected to arterial motorway systems on the immediate outskirts of a major city $(10 \mathrm{~km})$ around and within which there is considerable industrial activity and high levels of road traffic. In recent years an average of 300000 aircraft have passed through El Prat annually, but since 2009 the airport has been transformed by the addition of a new terminal capable of raising passenger numbers from 30 million to 55 million. Local factors of additional interest to a pollution study of this area include the fact that El Prat lies on the Llobregat Delta, confined (like Barcelona itself) by prominent hills to the northeast, and is subject to the influences of both sea breezes and industrial pollution plumes emanating from the Llobregat River valley.

\section{Experimental}

A mobile laboratory van (MUMAP - mobile unit for atmospheric pollution monitoring) was installed about $130 \mathrm{~m}$ from the major runway $(07 \mathrm{R}-25 \mathrm{~L})$, in the direction of the shore line (Fig. 1) from October 17th to November 16th, 2007. Depending on the meteorological conditions this lane was sometimes used also for landing. The levels of $\mathrm{PM}_{10}, \mathrm{PM}_{2.5}$ and $\mathrm{PM}_{1}$ were measured continuously by means of a laser-spectrometer dust monitor (Grimm Labortechnik GmbH \& Co. KG; model 1108) with 1-h resolution. Twelve-hour samples (10:00-22:00-10:00) of $\mathrm{PM}_{10}$ were collected on quartz micro-fibre filters (Schleicher and Schuell; QF20) by means of a high volume captor DIGITEL DH $80\left(30 \mathrm{~m}^{3} \mathrm{~h}^{-1}\right)$. Sampling was carried out continuously for the whole period. PM mass concentrations were determined by standard gravimetric procedures. The gravimetric data obtained were used to correct the $\mathrm{PM}_{10}$ measurements obtained with the laser spectrometer. A total of $59 \mathrm{PM}_{10}$ samples were analysed using the following procedure. A quarter of each filter was acid digested with a mixture of $\mathrm{HF}: \mathrm{HNO}_{3}: \mathrm{HClO}_{4}(5: 2.5: 2.5 \mathrm{ml})$, kept at $90{ }^{\circ} \mathrm{C}$ in a Teflon reactor for $6 \mathrm{~h}$, driven to dryness and redissolved with $2.5 \mathrm{ml}$ of $\mathrm{HNO}_{3}$ to make up a volume of $50 \mathrm{ml}$ with water) for the determination of major and trace elements. Inductively coupled plasma atomic emission spectrometry (ICPAES) analysis was instead applied for the measurement of major elements including $\mathrm{Al}, \mathrm{Ca}, \mathrm{K}, \mathrm{Mg}, \mathrm{Fe}, \mathrm{S}$ and $\mathrm{Na}$. The concentration of about 30 metals was determined (As, Ba, Bi, Cd, Ce, $\mathrm{Co}, \mathrm{Cr}, \mathrm{Cs}, \mathrm{Cu}, \mathrm{Ga}, \mathrm{Hf}$, La, Li, Mn, Mo, Nb, Ni, P, Pb, Rb, Sb, Sc, Se, Sn, Sr, Th, Ti, Tl, U, V, W, Y, Zn and Zr) by means of inductively coupled plasma mass spectrometry (ICP-MS) analysis. Another 1/4 of each filter was water leached to determine soluble ion concentrations by ion chromatography (sulfate,

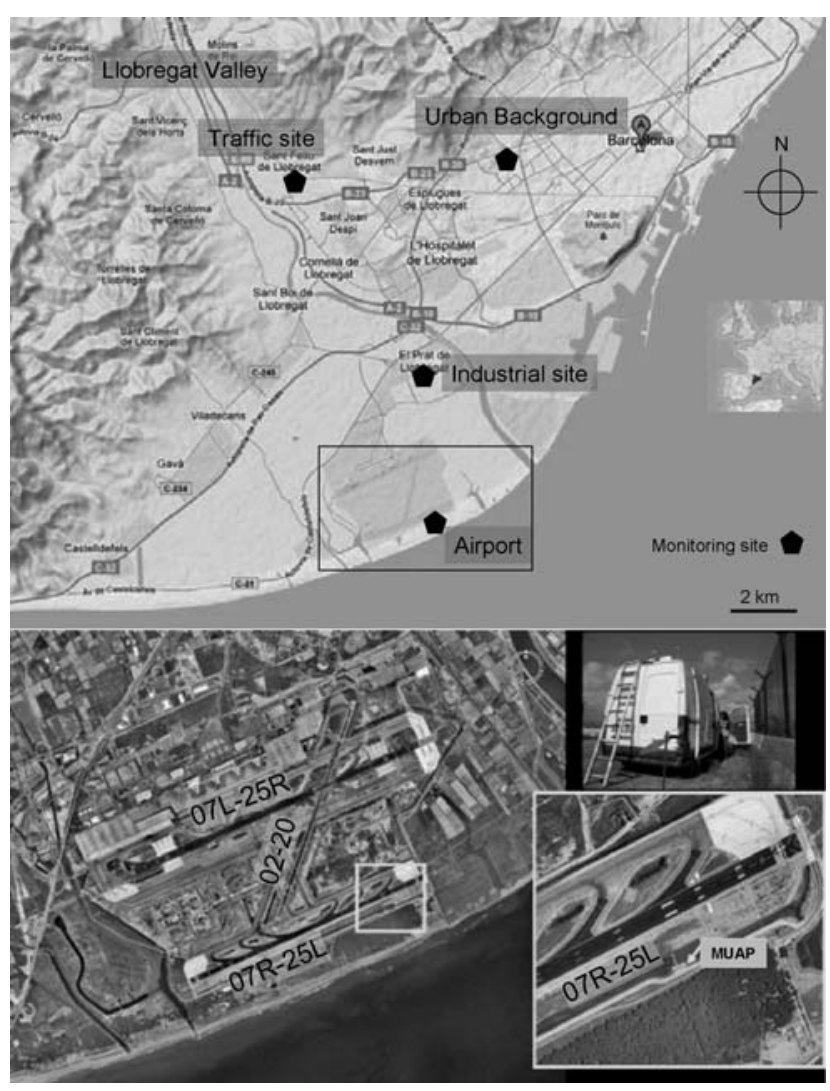

Fig. 1 Area of study and location of the MUMAP.

nitrate and chloride) and ion selective electrode (ammonium). A punch of $1.5 \mathrm{~cm}^{2}$ from the remaining part of the filter was used for the analysis of organic and elemental carbon (OC and EC) by a thermal-optical transmission technique ${ }^{15}$ using a Sunset Laboratory OCEC Analyser with the standard temperature programme. Moreover, $\mathrm{SiO}_{2}$ and $\mathrm{CO}_{3}=$ were indirectly determined on the basis of empirical factors $\left(\mathrm{Al} \times 1.89=\mathrm{Al}_{2} \mathrm{O}_{3}, 3 \times\right.$ $\mathrm{Al}_{2} \mathrm{O}_{3}=\mathrm{SiO}_{2}$ and $1.5 \times \mathrm{Ca}=\mathrm{CO}_{3}{ }^{=}$, mass ratios $\left.{ }^{16}\right)$. The addition of the above determinations accounted for $75-85 \%$ of the $\mathrm{PM}_{10}$ mass. The remaining undetermined mass is attributed to non-C atoms of organic matter and to the structural and adsorbed water that was not removed during the sample conditioning. The chemical components of the PM were grouped as (a) crustal or mineral (sum of $\mathrm{Al}_{2} \mathrm{O}_{3}, \mathrm{SiO}_{2}, \mathrm{CO}_{3}=\mathrm{Ca}, \mathrm{Fe}, \mathrm{K}, \mathrm{Mg}, \mathrm{Mn}$, Ti and $\mathrm{P}$ ); (b) marine component (sum of $\mathrm{Cl}^{-}, \mathrm{Na}$ and $\mathrm{Mg}^{2+}$ ); (c) organic carbon and elemental carbon, $\mathrm{OC}+\mathrm{EC}$; and (d) secondary inorganic aerosols, SIA (sum of $\mathrm{SO}_{4}{ }^{=}, \mathrm{NO}_{3}{ }^{-}$and $\mathrm{NH}_{4}{ }^{+}$).

Samplings of runway dust (runway 02-20; Fig. 2) were performed in two different points of the runway (one in the centre and one in the verge) following the procedure described by Amato et al. ${ }^{14}$ To this aim, take-off and landing operations on runway $02-20$ were stopped for $2 \mathrm{~h}$ and sampling operations were continuously radio-monitored from the tower control. Differently from other road sediment procedures ${ }^{17,18}$ consisting in collecting samples directly from road pavement by sweeping sediments and either sieving or inducing resuspension in the laboratory and extracting $\mathrm{PM}_{10}$ through size selective inlets, ${ }^{19,20}$ we developed a field resuspension chamber to directly vacuum, at an air flow rate of $251 \mathrm{~min}^{-1}$, the resuspended $\mathrm{PM}_{10}$ fraction of 


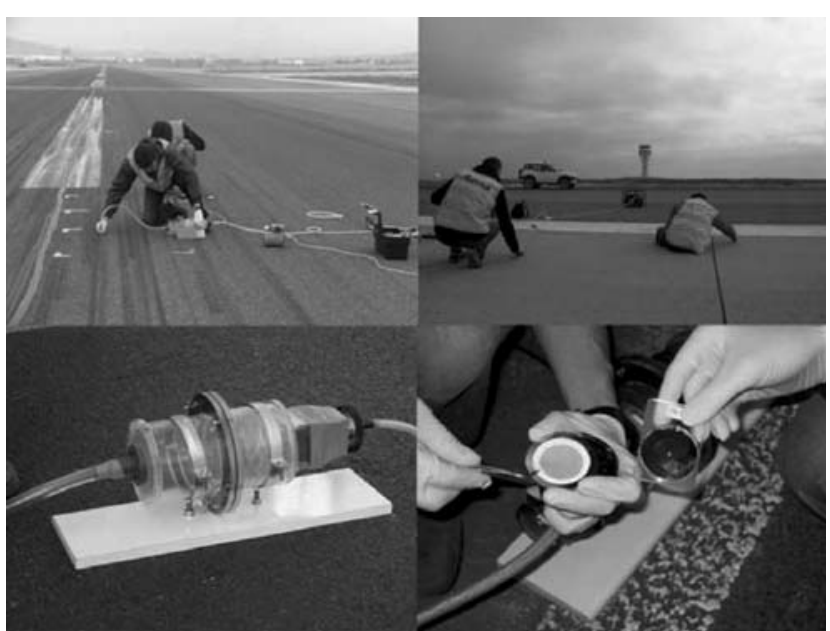

Fig. 2 Sampling of the $\mathrm{PM}_{10}$ fraction of runway (02-20) dust.

runway dust onto filters at sampling sites (Fig. 2). Thus road sediments were aspired from the pavement of the 02-20 runway, using a Becker pump powered by a Honda field generator (located at some distance downwind with respect to the sampling area). Particles were immediately in situ resuspended in a PVC deposition chamber and the particles small and/or light enough to be carried by the air current continued their journey through the system. These particles entered a Negretti stainless steel elutriation filter designed to allow passage to only $\mathrm{PM}_{10}$ grade material of average density. The particles able to penetrate this barrier were finally collected on $47 \mathrm{~mm}$ diameter fiber quartz or Teflon membrane filters. Particles with aerodynamic diameter $>10 \mu \mathrm{m}$ were deposited in the PVC chamber. Electrostatic adhesion might cause some losses of particles $<10 \mu \mathrm{m}$, which was not possible to quantify. Nevertheless this loss is likely to be negligible with respect to losses of traditional sampling procedures (i.e. sweeping).

The composition and morphology of both ambient $\mathrm{PM}_{10}$ particles and runway dust samples were also studied uncoated under an environmental scanning electron microscope (SEM, FEI QUANTA 200). Chemical analyses of individual particles were performed manually using energy dispersive X-ray microanalysis (EDX) with a working distance of $10 \mathrm{~mm}$, accelerating voltage of $20 \mathrm{kV}$, beam spot size number 2 with a beam current of approximately $1 \mu \mathrm{A}$, and a spectrum acquisition time of $30 \mathrm{~s}$ life time. Individual particles were analyzed at very high magnification to maximize the quality of the semi-quantitative results obtained using a low vacuum SEM.

\section{Meteorology}

The daily movement pathways of air-masses into the studied area during the monitoring campaign were assessed using the Hysplit model 4 with vertically modelled transport back-trajectories being calculated for 5 days at 500, 1500 and $2500 \mathrm{~m}$ above sea level. These interpretations were also coupled with information obtained from NAAPS (navy aerosol analysis and prediction system) aerosol dust concentration maps.

During the measurement period two main atmospheric conditions were observed, namely Atlantic advection and regional pollution episodes. The Atlantic advection episodes are characterized by the renewal of the air masses with subsequent reduction in the ambient air levels of $\mathrm{PM}$, as shown in the following paragraphs. Two periods were characterized by this Atlantic advection atmospheric setting, namely 18-20/10/2007 and 29-31/10/2007. In contrast, regional pollution episodes were more common, occurring in four episodes: 17-18/10/2007; 24-28/ 10/2007; 1-5/11/2007 and 8-14/11/2007. These regional episodes are characterized by low pressure gradient and low circulation, driven mainly by sea breeze circulation, with consequent atmospheric stagnation and pollutant build-up. ${ }^{21}$

Meteorological data (precipitation, direction and wind velocity every $5 \mathrm{~min}$ ) during the measurement campaign were collected at a measurement station located within the El Prat Airport and run by the Environmental Department of the Spanish Airports and Air Navigation (AENA). Dominant wind patterns observed during the study period are mainly controlled by the daily cycle of alternating land $\left(290-350^{\circ}\right)$ and sea breezes $\left(45-150^{\circ}\right)$. In this system, an overnight land breeze blows from late evening (around 21:00-22:00) to morning (around 09:0010:00), and is canalized through the Llobregat Valley resulting in an almost constant wind direction from the NNW. In contrast the daytime sea breeze which develops lacks this valley channelling effect and instead blows onshore from a range of directions from NE to SW.

\section{Results and discussion}

\subsection{PM concentrations}

The mean levels of $\mathrm{PM}_{10}, \mathrm{PM}_{2.5}$ and $\mathrm{PM}_{1}$ for the study period were 48,21 and $17 \mu \mathrm{g} \mathrm{m}^{-3}$, respectively, as measured by the laser spectrometer and corrected (only for $\mathrm{PM}_{10}$ ) by comparison with gravimetric levels (slope $=0.73 ; \mathrm{R}^{2}=0.68$ ). $\mathrm{PM}_{10}$ levels were also compared with gravimetric $\mathrm{PM}_{10}$ data obtained at three other monitoring stations, these belonging to the local air-quality network: an urban background site (CSIC), a traffic site (with some industrial influence; St. Feliu) and an industrial site (El Prat) heavily affected by the high velocity railway construction works with correlation coefficients $0.63,0.70$ and 0.74 respectively. All of these sites correlated well with $\mathrm{PM}_{10}$ concentrations measured at Barcelona Airport (Fig. 3), although both the traffic and industrial sites registered predictably higher

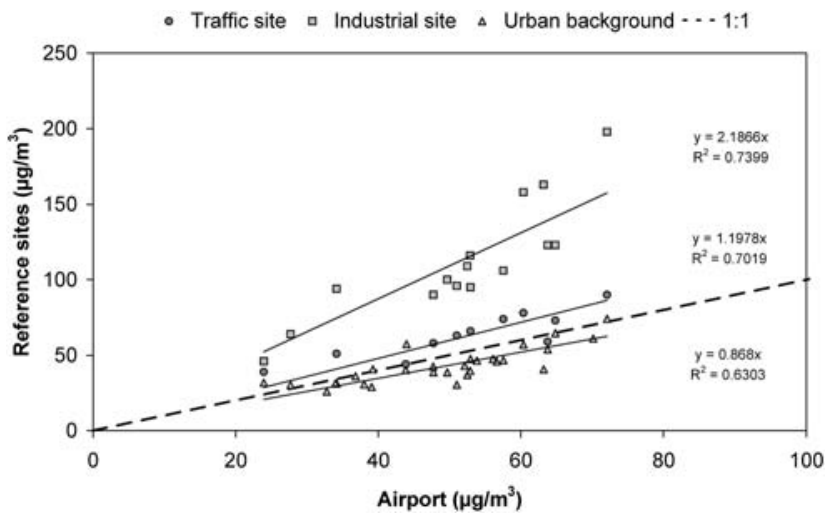

Fig. 3 Correlation between $\mathrm{PM}_{10}$ concentrations at El Prat Airport $(x$ axis) and three reference sites ( $y$ axis) in the nearby area. Dates are those in common between pairs of sites. 
levels (slopes of 1.2 and 2.2 respectively). Conversely the urban background site, located in the NW of the city within the university campus (Fig. 1), registered an average of $6 \mu \mathrm{g} \mathrm{m}^{-3}$ less than our airport runway station. Additional pollution sources are therefore located in the airport, although such contributions are slight when compared to traffic and industrial emissions. The $\mathrm{PM}_{x}$ concentrations were also examined in relation to the total number of take-offs, landings, and for variations in use of particular runways, but no correlations were found between $\mathrm{PM}_{x}$ levels with number of departures (Fig. 4).

Fig. 4 shows the average daily evolution of $\mathrm{PM}_{10}, \mathrm{PM}_{2.5}, \mathrm{PM}_{1}$, wind direction and total number of departures during the measurement period. As, shown, the registered PM levels followed an almost constant pattern with the following main characteristics:

(i) A rise in $\mathrm{PM}_{10}$ concentrations to around 50-60 $\mu \mathrm{g} \mathrm{m}^{-3}$ was regularly observed starting during the evening (20:00) and declining the following morning (08:00) with the development of the sea breeze $\left(0-180^{\circ}\right)$. During these hours were also registered the highest mean levels of $\mathrm{PM}_{2.5}$ and $\mathrm{PM}_{1}$ to around $30 \mu \mathrm{g} \mathrm{m}^{-3}$ and $25 \mu \mathrm{g} \mathrm{m}^{-3}$, respectively. Such elevated nocturnal concentrations are attributed to the land breeze transport of pollutants from inland through the Llobregat Valley. Apart from urban and motorway traffic, PM emissions in this valley originate mainly from an important industrial cluster of ferrous and non-ferrous smelters, cement kilns and chemical industries. During these land-sourced breezes $\mathrm{PM}_{1} / \mathrm{PM}_{10}$ ratios were the highest $(>0.5)$, supporting the likely anthropogenic origin of much of the aerosol loading.

(ii) Starting from around 10:00, and until 19:00, $\mathrm{PM}_{10}$ levels around $40 \mu \mathrm{g} \mathrm{m}^{-3}$ were typically registered and mainly related to the relatively cleansing effect of sea breezes pushing the pollutants inland away from the coast. During this scenario mean values of uncorrected $\mathrm{PM}_{2.5}$ and $\mathrm{PM}_{1}$ were $15 \mu \mathrm{g} \mathrm{m}^{-3}$ and $11 \mu \mathrm{g}$ $\mathrm{m}^{-3}$, while $\mathrm{PM}_{1} / \mathrm{PM}_{10}$ was lower (0.37) than during land breeze transport, indicating a high proportion of coarser particles $\left(\mathrm{PM}_{2.5-10}\right)$. As shown in the next paragraph, the chemical analysis of $12 \mathrm{~h} \mathrm{PM}_{10}$ filters revealed a dominance of sea salt particles when $\mathrm{PM}_{1} / \mathrm{PM}_{10}$ were low with a notable exception of mineral dust pollution peak on 15th November 2007 (6.0 $\mu \mathrm{g} \mathrm{Ca} \mathrm{m}^{-3}, 3.3$ $\mu \mathrm{g} \mathrm{Al} \mathrm{m}{ }^{-3}$ and $\left.0.5 \mu \mathrm{g} \mathrm{Mg} \mathrm{m}^{-3}\right)$. The dominant wind direction at

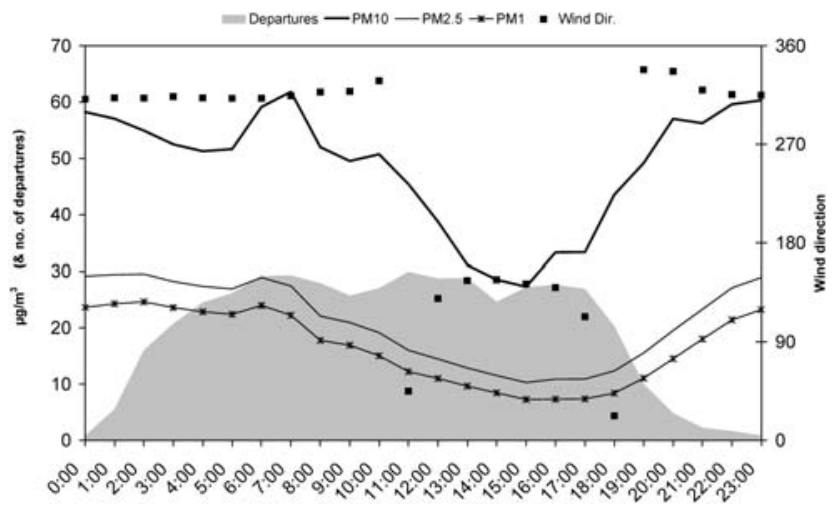

Fig. 4 Mean hourly levels of $\mathrm{PM}_{10}$ (GRIMM corrected), $\mathrm{PM}_{2.5}$ (uncorrected optical counter), $\mathrm{PM}_{1}$ (uncorrected optical counter) and wind direction during the whole measurement period. Shaded area represents number of departures (also on the left axis). the time was NW, directly in the path of building works for the new airport terminal: presumably this exceptional pollution episode was the result of a dust cloud generated during construction activities.

\subsection{Chemical composition of $\mathbf{P M}_{10}$}

Table 1 reports the levels of chemical species analysed from the ambient $\mathbf{P M}_{10}$ samples. A total of $59 \mathrm{PM}_{10}$ filters were analysed. In this table mean values, standard deviations, minimum and maximum concentrations are reported in $\mu \mathrm{g} \mathrm{m}^{-3}$ and $\mathrm{ng} \mathrm{m}^{-3}$ for major and trace elements, respectively. Concerning the major elements, mineral matter represents the main component of the

Table 1 Mean concentrations, standard deviations, min. and max. values for major $\left(\mu \mathrm{g} \mathrm{m}^{-3}\right)$ and trace elements $\left(\mathrm{ng} \mathrm{m}^{-3}\right)$ among $59 \mathrm{PM}_{10}$ samples. ns: not soluble; <DL: below detection limit

\begin{tabular}{|c|c|c|c|c|}
\hline$\mu \mathrm{g} \mathrm{m}^{-3}$ & Mean & St. deviation & Min. & Max. \\
\hline $\mathrm{OC}$ & 6.8 & 2.1 & 3.6 & 12.7 \\
\hline $\mathrm{EC}$ & 2.4 & 1.2 & 0.5 & 6.8 \\
\hline $\mathrm{Al}$ & 0.8 & 0.4 & 0.1 & 2.0 \\
\hline $\mathrm{Ca}$ & 3.2 & 1.7 & 0.5 & 7.5 \\
\hline $\mathrm{Na}$ & 1.5 & 0.9 & 0.4 & 5.2 \\
\hline $\mathrm{Mg}_{\mathrm{ns}}$ & 0.19 & 0.11 & 0.03 & 0.50 \\
\hline $\mathrm{Mg}^{2+}$ & 0.20 & 0.08 & 0.08 & 0.50 \\
\hline $\mathrm{Fe}$ & 1.3 & 0.6 & 0.3 & 2.8 \\
\hline $\mathrm{S}$ & 1.4 & 0.4 & 0.6 & 2.3 \\
\hline $\mathrm{K}_{\mathrm{ns}}$ & 0.19 & 0.13 & 0.02 & 0.59 \\
\hline $\mathrm{K}^{+}$ & 0.4 & 0.3 & 0.1 & 2.2 \\
\hline $\mathrm{SO}_{4}=$ & 3.5 & 1.1 & 1.1 & 6.7 \\
\hline $\mathrm{NO}_{3}^{-}$ & 5.0 & 3.0 & 1.1 & 14.4 \\
\hline $\mathrm{Cl}^{-}$ & 1.4 & 1.1 & 0.1 & 6.3 \\
\hline $\begin{array}{l}\mathrm{NH}_{4}^{+} \\
\mathbf{n g ~ m}^{-3}\end{array}$ & 1.2 & 0.7 & 0.2 & 3.1 \\
\hline $\mathrm{Li}$ & 0.9 & 0.4 & 0.2 & 2.0 \\
\hline $\mathrm{Sc}$ & 0.48 & 0.38 & $<\mathrm{DL}$ & 1.17 \\
\hline $\mathrm{P}$ & 41.3 & 12.3 & 20.0 & 69.0 \\
\hline $\mathrm{Ti}$ & 46.9 & 22.5 & 7.7 & 106.1 \\
\hline V & 17.7 & 9.7 & 5.8 & 37.4 \\
\hline $\mathrm{Cr}$ & 12.0 & 6.3 & 2.5 & 28.3 \\
\hline $\mathrm{Mn}$ & 40.1 & 20.4 & 7.7 & 82.9 \\
\hline Co & 0.4 & 0.1 & 0.2 & 0.7 \\
\hline $\mathrm{Ni}$ & 6.1 & 2.6 & 2.1 & 12.2 \\
\hline $\mathrm{Cu}$ & 50.1 & 24.0 & 5.1 & 121.9 \\
\hline $\mathrm{Zn}$ & 261.8 & 154.4 & 29.3 & 646.6 \\
\hline $\mathrm{Ga}$ & 0.38 & 0.16 & 0.08 & 0.74 \\
\hline As & 2.4 & 1.4 & 0.7 & 6.3 \\
\hline $\mathrm{Se}$ & 1.09 & 2.08 & 0.15 & 14.66 \\
\hline $\mathrm{Rb}$ & 1.7 & 0.7 & 0.5 & 3.2 \\
\hline $\mathrm{Sr}$ & 7.8 & 3.3 & 2.0 & 19.6 \\
\hline $\mathrm{Y}$ & 0.5 & 0.2 & 0.2 & 0.8 \\
\hline $\mathrm{Zr}$ & 12.99 & 3.97 & 0.01 & 18.76 \\
\hline $\mathrm{Nb}$ & 0.26 & 0.11 & 0.04 & 0.55 \\
\hline Mo & 6.72 & 4.07 & 0.01 & 14.84 \\
\hline $\mathrm{Cd}$ & 1.0 & 2.1 & 0.2 & 12.7 \\
\hline $\mathrm{Sn}$ & 7.2 & 3.7 & 2.0 & 19.8 \\
\hline $\mathrm{Sb}$ & 4.0 & 2.3 & 0.7 & 11.5 \\
\hline Cs & 0.13 & 0.11 & $<\mathrm{DL}$ & 0.35 \\
\hline $\mathrm{Ba}$ & 36.3 & 15.0 & 12.5 & 77.3 \\
\hline $\mathrm{La}$ & 0.4 & 0.2 & 0.1 & 0.8 \\
\hline $\mathrm{Ce}$ & 0.99 & 0.41 & 0.19 & 2.08 \\
\hline Hf & 0.74 & 0.18 & 0.01 & 1.01 \\
\hline $\mathrm{W}$ & 0.67 & 0.36 & 0.17 & 1.60 \\
\hline $\mathrm{Tl}$ & 0.36 & 0.31 & $<\mathrm{DL}$ & 1.75 \\
\hline $\mathrm{Pb}$ & 41.5 & 25.6 & 4.5 & 98.9 \\
\hline $\mathrm{Bi}$ & 1.78 & 2.08 & $<\mathrm{DL}$ & 8.90 \\
\hline Th & 0.2 & 0.1 & $<\mathrm{DL}$ & 0.5 \\
\hline U & 0.2 & 0.1 & 0.1 & 0.4 \\
\hline
\end{tabular}


$\mathrm{PM}_{10}$ mass with a contribution of $18.5 \pm 7.0 \mu \mathrm{g} \mathrm{m}^{-3}$ corresponding to about $38 \%$ of $\mathrm{PM}_{10}$. The measured levels of secondary inorganic aerosol (SIA) (about $10 \mu \mathrm{g} \mathrm{m}^{-3}$ corresponding to $20 \%$ of $\mathrm{PM}_{10}$ ) were lower (in $\mu \mathrm{g} \mathrm{m}^{-3}$ ) than mean annual levels registered in the metropolitan area of Barcelona. ${ }^{22}$ This is attributed mainly to the low concentration of sulfate registered during the El Prat measurement campaign as a consequence of reduced secondary sulfate concentrations during the coldest months of the year. Average sea salt concentrations are $3 \mu \mathrm{g} \mathrm{m}^{-3}$, representing $6 \%$ of the $\mathrm{PM}_{10}$ total mass and are within the normal range for urban coastal sites in Spain $(1.5-5 \mu \mathrm{g}$ $\left.\mathrm{m}^{-3}\right) \cdot{ }^{23}$ Levels of OC $+\mathrm{EC}$ represent $19 \%$ of the $\mathrm{PM}_{10}$ mass $\left(9.2 \mu \mathrm{g} \mathrm{m}^{-3}\right)$, this being rather high taking into account the range for Spanish urban background stations (3.3-9.4 $\left.\mathrm{\mu g} \mathrm{m}^{-3},{ }^{24}\right)$ and the fact that major motorways are at some distance $(4 \mathrm{~km})$ of the monitoring site; this suggests a possible contribution from aircraft exhaust. Furthermore the time-evolution of the different types of aerosol indicated that the sum OC + EC was the only one aerosol with a similar tendency for the number of departures at the $07 \mathrm{~L}-25 \mathrm{R}$ runway (Fig. 5). A comparison with simultaneous $\mathrm{PM}_{10}$ samples collected at the urban background site (CSIC) showed good correlation for OC and EC $\left(\mathrm{R}^{2}=0.75\right.$ and 0.73 , respectively) but approximately $2 \mu \mathrm{g} \mathrm{OC} \mathrm{m}{ }^{-3}$ additional at El Prat Airport, while EC was nearly the same. The good correlation is interpreted as driven by the land-breeze, which transports the urban pollution towards the airport at night time, while the difference in OC could be attributable to aircraft emissions. Another indication of PM atmospheric pollution being directly attributable to aircraft traffic is the similar trend between $\mathrm{Cu}$ and $\mathrm{Sb}$ concentrations (metals used as tracers of brake pads ${ }^{25}$ ) and the number of landings on the runway (Fig. 6).

The ambient air concentrations of both major and trace elements registered at El Prat Airport were compared with the range of urban background concentrations usually registered in Spain $^{24}$ and in the Barcelona urban background station. ${ }^{22}$ Despite the fact that the El Prat area lies on the outskirts of the city, and is bordered by the sea, estuarine marches, and agricultural land, the concentrations of many elements present in atmospheric aerosols are unusually high. In particular, levels of $\mathrm{Ca}, \mathrm{Fe}, \mathrm{K}, \mathrm{Zn}, \mathrm{Mn}, \mathrm{V}, \mathrm{Cr}, \mathrm{Sn}, \mathrm{Zr}, \mathrm{Mo}, \mathrm{As}, \mathrm{Bi}, \mathrm{Cd}, \mathrm{Y}, \mathrm{Li}, \mathrm{Sc}, \mathrm{Pr}$, Cs and Hf all exceed their typical "Spanish urban background" (SUB) range. Other PM components such as (OC + EC), Na, Ce, $\mathrm{Se}, \mathrm{Cl}^{-}, \mathrm{SiO}_{2}, \mathrm{Al}_{2} \mathrm{O}_{3}, \mathrm{Mg}, \mathrm{Ti}, \mathrm{Pb}, \mathrm{Ba}, \mathrm{Ni}, \mathrm{Sr}, \mathrm{Rb}, \mathrm{W}, \mathrm{U}, \mathrm{Ga}$ and light rare earth elements $(\mathrm{La}-\mathrm{Sm})$ show concentrations within

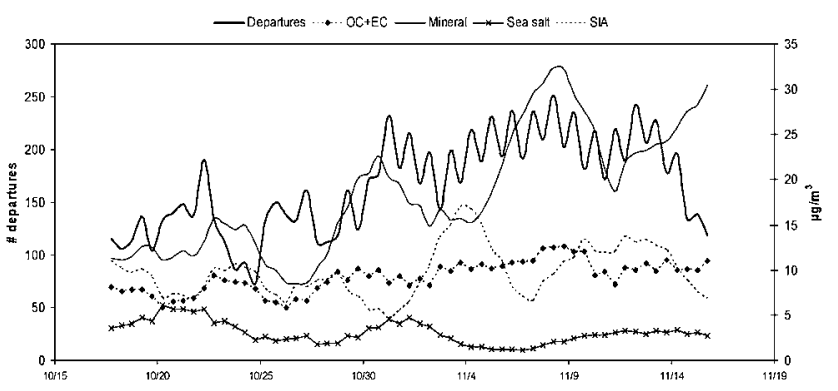

Fig. 5 Time evolution of total airport departures and ambient levels of different types of aerosol components in $\mathrm{PM}_{10}$ (sliding average of 5 samples).

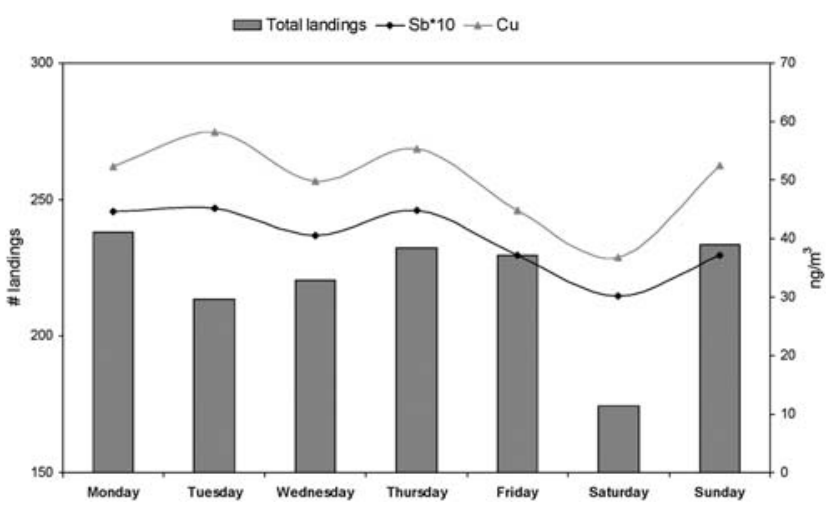

Fig. 6 Comparison between number of landings in the runway and ambient levels of $\mathrm{Cu}$ and $\mathrm{Sb}$ (amplified by a factor of 10) in $\mathrm{PM}_{10}$.

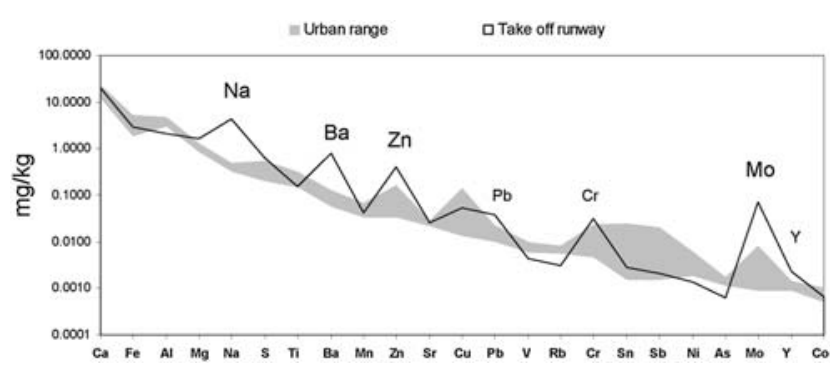

Fig. 7 Major and trace element levels in the deposited runway dust (mean value) compared with the urban concentration range of road dust in Barcelona (Amato et al., 2009). ${ }^{14}$ Species with concentration below detection limit were omitted.

their SUB range but are comparable to or even higher than the levels registered in Barcelona city.

Fig. 7 shows the chemical profile of the collected $\mathrm{PM}_{10}$ runway dust compared with the urban concentration range of road dust collected in Barcelona. ${ }^{14}$ Higher concentrations of $\mathrm{Na}, \mathrm{Ba}, \mathrm{Zn}$, and Mo were measured in the runway dust when compared with the urban road dust (Fig. 7). This unusual chemical grouping is attributed to a combination of marine aerosol deposited on the runway $(\mathrm{Na})$ and the effects of airplane pneumatic tyre wear during landing ( $\mathrm{Ba}, \mathrm{Zn}$ and $\mathrm{Mo}$ ). Some support for this interpretation is provided by the observation that the lowest concentrations of the trace elements $\mathrm{Cu}$ and $\mathrm{Sb}$ coincide with the day (Saturday) with the lowest average number of landings (Fig. 6)

\subsection{Source apportionment}

A Varimax rotated factor analysis was performed to identify the main chemical groupings and likely sources of airborne $\mathrm{PM}_{10}$ collected at the airport. Receptor modelling techniques are based on the evaluation of data acquired at receptor sites, and most of them do not require previously identified emission sources. ${ }^{26,27}$ Principal component analysis (PCA) was applied to obtain such emission sources (factors), in our analyses accounting for at least $85 \%$ of the variance of the dataset. We have not presented any factor loadings with low significance (between 0.3 and -0.3 ). The quantitative determinations of the source contributions were based on multilinear regression analysis (MLRA), in which the bulk PM concentration was used as a dependent variable, and 
the absolute factor score matrix as the independent variables. The mean daily contributions of the different sources to PM levels were thus calculated, as well as the contributions of the sources to specific PM components (e.g. trace elements).

The source apportionment analysis indicates the presence of 5 chemical groupings within the $\mathrm{PM}_{10}$ samples (Table 2). The first of these (factor 1) shows a strong correlation between metals/metalloids (Ni, Sb, V, Sn, Cu, As, $\mathrm{Zn}, \mathrm{Cd}$ and $\mathrm{Bi}$ ) and elemental carbon (EC), with factor loadings $>0.71$. Elemental carbon is sourced principally from hydrocarbon combustion, and its correlation with metalliferous aerosols indicates a likely derivation of factor 1 elements from road traffic and industrial emissions. This anthropogenic material forms the dominant component in our $\mathrm{PM}_{10}$ samples (50\% factor variance), and was commonly most conspicuous during night-time pollution episodes when metalliferous industrial and urban contaminates were transported seawards after the daytime reversal of sea breezes. $^{21}$

The second chemical grouping (loading factor 2 on Table 2) comprises elements characteristic of crustal rock forming minerals, especially silicates ( $\mathrm{Al}, \mathrm{Ti}, \mathrm{K}, \mathrm{Rb}, \mathrm{Li}, \mathrm{Ce}, \mathrm{La}$ ), oxides, carbonates $(\mathrm{Mg}, \mathrm{Ca}, \mathrm{Sr})$ and possibly fine detrital accessory minerals such as monazite, zircon and rutile $(\mathrm{Ce}, \mathrm{La}, \mathrm{Zr}, \mathrm{Nb}){ }^{28}$ This factor, which represents $16 \%$ of the $\mathrm{PM}_{10}$ variance, presumably reflects the presence of natural soil and rock particles and their frequent resuspension by anthropogenic activities (such as road traffic, aircraft, and building work for the new airport terminal). The ongoing construction activity within the airport perimeter, mainly associated with work on the new terminal and a parking area close to the control tower, had a clearly detectable influence on $\mathrm{PM}_{10}$ loadings which dropped appreciably during the weekends (Fig. 8).

The third factor revealed by the source apportionment analysis comprises the marine aerosol component, with $\mathrm{Na}, \mathrm{Cl}^{-}$and $\mathrm{Mg}$

Table 2 Factor loadings obtained for the five principal components; ns: not soluble. In bold are species with values higher than 0.5 or lower than $-0.5$

\begin{tabular}{|c|c|c|c|c|c|c|c|c|c|}
\hline \multicolumn{2}{|c|}{ Traffic/Industrial } & \multicolumn{2}{|c|}{$\begin{array}{l}\text { Mineral/ } \\
\text { Works }\end{array}$} & \multicolumn{2}{|c|}{ Sea salt } & \multicolumn{2}{|c|}{ Secondary } & \multicolumn{2}{|c|}{ Biomass } \\
\hline $\mathbf{N i}$ & 0.90 & $\mathbf{M g}_{\mathrm{ns}}$ & 0.98 & $\mathbf{M g}^{2+}$ & -0.97 & $\mathrm{NH}_{4}{ }^{+}$ & 0.87 & $\mathbf{K}^{+}$ & 0.73 \\
\hline Sb & 0.88 & Al & 0.97 & $\mathbf{C l}^{-}$ & -0.93 & $\mathrm{NO}_{3}{ }^{-}$ & 0.79 & $\mathbf{P b}$ & 0.62 \\
\hline V & 0.88 & $\mathbf{K}_{\mathrm{ns}}$ & 0.97 & $\mathbf{N a}$ & -0.92 & $\mathrm{SO}_{4}^{2-}$ & 0.73 & & \\
\hline Sn & 0.87 & $\mathbf{T i}$ & 0.96 & & & $\mathrm{OC}^{\circ}$ & 0.40 & & \\
\hline $\mathbf{C u}$ & 0.84 & $\mathbf{L i}$ & 0.95 & & & V & 0.30 & & \\
\hline As & 0.83 & $\mathrm{Ca}$ & 0.95 & & & & & & \\
\hline $\mathrm{Zn}$ & 0.82 & $\mathbf{L a}$ & 0.93 & & & & & & \\
\hline EC & 0.77 & $\mathrm{Sr}$ & 0.91 & & & & & & \\
\hline Cd & 0.74 & $\mathbf{R b}$ & 0.89 & & & & & & \\
\hline $\mathbf{B i}$ & 0.72 & Co & 0.76 & & & & & & \\
\hline $\mathrm{Fe}$ & 0.68 & Nb & 0.76 & & & & & & \\
\hline $\mathbf{P b}$ & 0.65 & Cs & 0.66 & & & & & & \\
\hline Mn & 0.61 & $\mathbf{G a}$ & 0.65 & & & & & & \\
\hline $\mathbf{G a}$ & 0.61 & $\mathrm{Fe}$ & 0.49 & & & & & & \\
\hline OC & 0.59 & $\mathrm{Zr}$ & 0.48 & & & & & & \\
\hline Co & 0.59 & $\mathrm{OC}$ & 0.44 & & & & & & \\
\hline $\mathrm{Nb}$ & 0.47 & $\mathrm{Mn}$ & 0.38 & & & & & & \\
\hline Cs & 0.45 & $\mathrm{Cu}$ & 0.35 & & & & & & \\
\hline $\mathrm{NO}_{3}^{-}$ & 0.35 & $\mathrm{Sb}$ & 0.33 & & & & & & \\
\hline $\mathrm{Zr}$ & 0.33 & & & & & & & & \\
\hline $\mathrm{Cr}$ & 0.33 & & & & & & & & \\
\hline Variance $(\%)$ & 50 & & 16 & & 8 & & 5 & & 4 \\
\hline
\end{tabular}
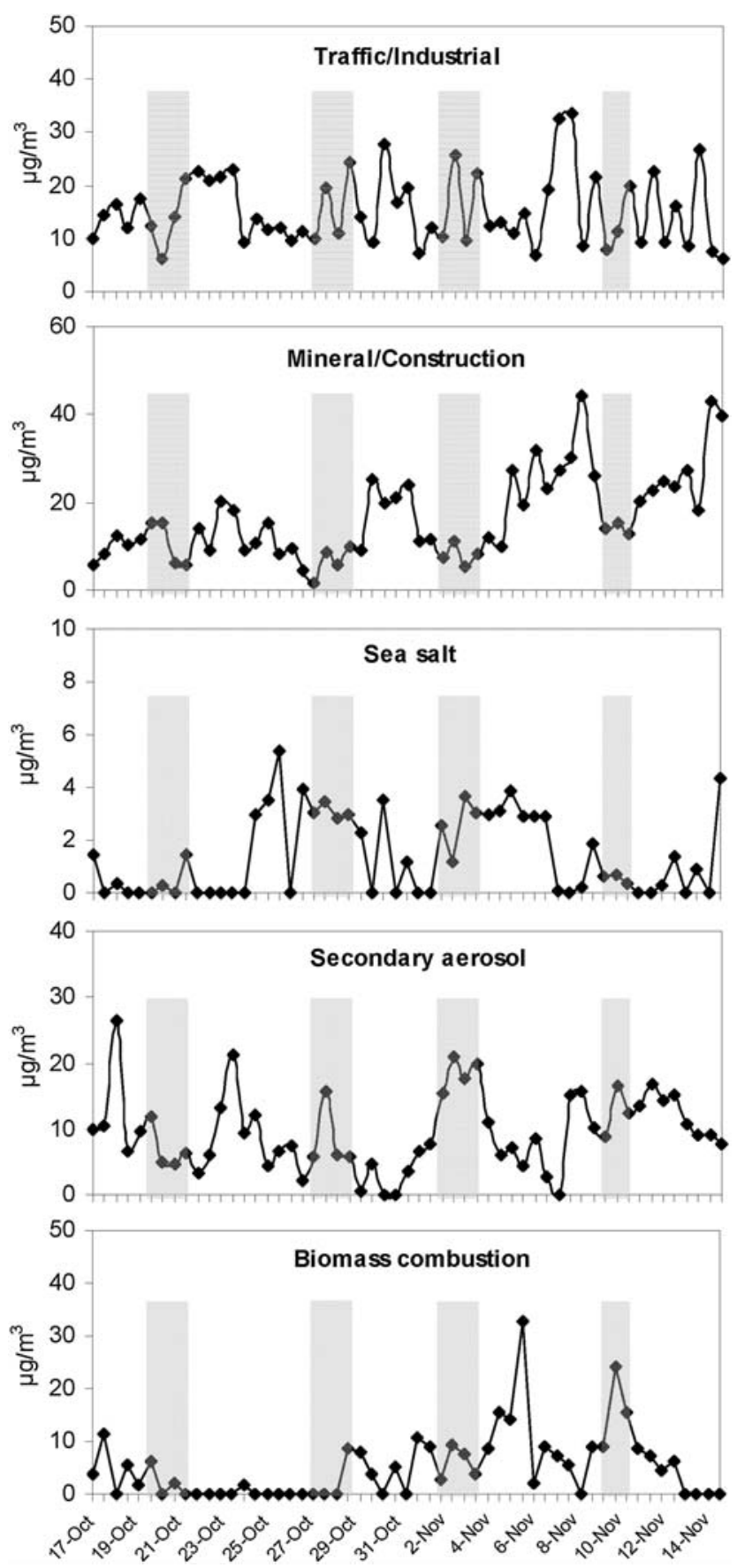

Fig. 8 Time evolution of source contributions for each of the main PM factors/sources contribution along the study period. Shaded bars are weekend samples.

showing a negative factor loading $>0.91$ (Table 2). This component is inversely correlated with the anthropogenic factor 1 , but is of relatively minor importance ( $8 \%$ variance). During the monitoring period daytime sea breezes were generally very light: at other times of the year the marine component would be much greater. Factor 4, slightly less important than the marine factor, comprises the ionic components of ammonium nitrate and sulfate $\left(\mathrm{NH}_{4}{ }^{+}, \mathrm{NO}_{3}{ }^{-}, \mathrm{SO}_{4}{ }^{2-}\right.$ : loading factor 0.72 ; variance $5 \%$ ). These chemical salts are characteristic of secondary aerosols and show some correlation with OC and V, suggesting a link with fuel 
oil combustion. ${ }^{29}$ A likely local source for such aerosols is the busy Barcelona port area, which lies immediately NE of the airport. Finally, $\mathrm{K}^{+}$identifies a biomass burning factor (variance $4 \%$ ), never detected in previous factor analysis studies in the city of Barcelona, ${ }^{30-32}$ but important here given the agricultural nature of much of the deltaic land surrounding the airport.

Given the identification of these five principal factors contributing to ambient $\mathrm{PM}_{10}$ concentrations at the airport, it becomes possible to estimate the amount of mass contributed by each of the main PM sources during the monitoring period (Fig. 8). According to this calculation, around two-thirds of the $\mathrm{PM}_{10}$ sampled came from either building works (33\%: $16.4 \mu \mathrm{g}$ $\mathrm{m}^{-3}$ ) or traffic and industrial emissions $\left(31 \%\right.$ : $\left.15.2 \mu \mathrm{g} \mathrm{m}^{-3}\right)$. Secondary aerosols (mostly ammonium salts) formed the next most abundant group (19\%: $\left.9.5 \mu \mathrm{g} \mathrm{m}^{-3}\right)$, followed in turn by biomass burning $\left(10 \%: 5.1 \mu \mathrm{g} \mathrm{m}^{-3}\right)$. Finally, marine salts were modelled as counting for only a very small proportion of the total $\mathrm{PM}_{10}$ mass (3\%: $\left.1.4 \mu \mathrm{g} \mathrm{m}^{-3}\right)$, revealing a small underestimation as compared with chemical concentrations $\left(\mathrm{Na}, \mathrm{Mg}^{2+}\right.$ and $\mathrm{Cl}^{-}$in the $\mathrm{PM}_{10}$ filters yielded a somewhat higher mass: $4 \%: 2.1 \mu \mathrm{g} \mathrm{m}^{-3}$ ). In general, there is a good correlation between the modelled mass calculations, and the actual measured mass $\left(\mathrm{R}^{2}=0.82\right)$.

Having identified the main $\mathrm{PM}_{10}$ sources it is interesting to consider the data when particulate air pollution was at its highest, i.e. when 12-h average concentrations exceeded $50 \mu \mathrm{g} \mathrm{m}^{-3}$. During the study period 24 such transient exceedences of $>50 \mu \mathrm{g}$ $\mathrm{m}^{-3}$ were registered, and a majority of these $(64 \%)$ could be clearly attributed either to local construction works $(36 \%)$ or traffic/industrial contamination (28\%). Secondary aerosols, probably forming from the nearby port, industry and road traffic gaseous emissions, formed the third most important group (18\%) during these "worst case" days, followed by local agricultural biomass combustion $\mathrm{PM}_{10}(12 \%)$. Although the intrusion of silicate dust derived from North Africa is a relatively commonplace event in the Barcelona area, during the study period no such exotic $\mathrm{PM}_{10}$ arrivals took place.

\subsection{Corroded airframe $P M$}

Routine study of $\mathrm{PM}_{10}$ filters under SEM reveals the normal range of geological rock forming mineral particles, PM of industrial/ traffic origin, chlorides (marine-derived cubic halite), sulfates (both gypsum, $\mathrm{CaSO}_{4} \cdot 2 \mathrm{H}_{2} \mathrm{O}$, and barite, $\mathrm{BaSO}_{4}$ ), traffic generated soot, and particles of biological origin such as pollen grains. The geological component comprises mostly silicates (quartz, clay minerals and feldspars), although both the carbonates calcite and dolomite were also recognised. With regard to the purely anthropogenic component (i.e. excluding resuspended geological $\mathrm{PM}$ ), a range of industrial fly ashes and metallic particles are present. Most of these metalliferous particles comprise Fe oxides, but can also occur with $\mathrm{Cu}, \mathrm{Zn}, \mathrm{Cr}$, Ni, or $\mathrm{Mo}$.

The most interesting observation under SEM, however, was the relatively common presence in the ambient $\mathrm{PM}_{10}$ samples of platy aluminous PM derived from airframe corrosion. Metals used in airframe construction constitute one of the more unusual and highly specific sources for anthropogenic particles present in the atmosphere and runway dusts. Metalliferous materials forming the body and wings of aircraft are subject to degradation over time, notably by the processes of stress corrosion cracking and exfoliation. ${ }^{33-35}$ These processes cause microscopic intergranular corrosion and failure along grain boundaries, with corrosion products wedging between thin sheets of elongate metal grains. ${ }^{36}$ Certain environmental conditions such as high humidity and coastal settings with abundant atmospheric salt particles have long been known to promote corrosion, ${ }^{37-39}$ making coastal airports such as Barcelona potentially more susceptible sites than others.

The skin of the fuselage and wings of modern aircraft is composed mainly of stressed aluminium alloyed with minor amounts of other metals such as $\mathrm{Cu}, \mathrm{Zn}$ and/or $\mathrm{Mg} .{ }^{39}$ The main disadvantage of using $\mathrm{Al}$ alloys is that the presence of other metals makes the material less resistant to corrosion, as opposed to pure $\mathrm{Al}$ which is chemically inert but has poor structural strength. A commonly employed method to reduce corrosion damage to aircraft exteriors is to pressure-weld a thin layer of pure aluminium to the alloy. In our SEM study both pure Al and Al alloys were observed, and all were thin and plate-shaped, analogous in form to flakes of geological phyllosilicates (Fig. 9). The morphology of these airframe flakes is controlled by their pronounced anisotropic fabric which results from the narrow width of individual pancake-shaped metal grains (commonly 5-25 $\mu \mathrm{m}$ thick) in these rolled high-strength aluminous materials. ${ }^{36}$ Corrosion of such anisotropic materials typically takes the form of directional attack parallel to the foliation defined by elongate grain boundaries, resulting in a leafing action and the progressive generation of a degraded texture we term hojaldre (similar to flaky pastry). Pervasive development of this corrosion will produce numerous intergranular separations propagating parallel to the plane of the metal sheet, promoting the loss of individual flakes from exposed surfaces of aircraft.

The presence of aluminous PM flakes was observed in many of the filter samples collected during the monitoring period, and in many cases was accompanied by an observable increase in total
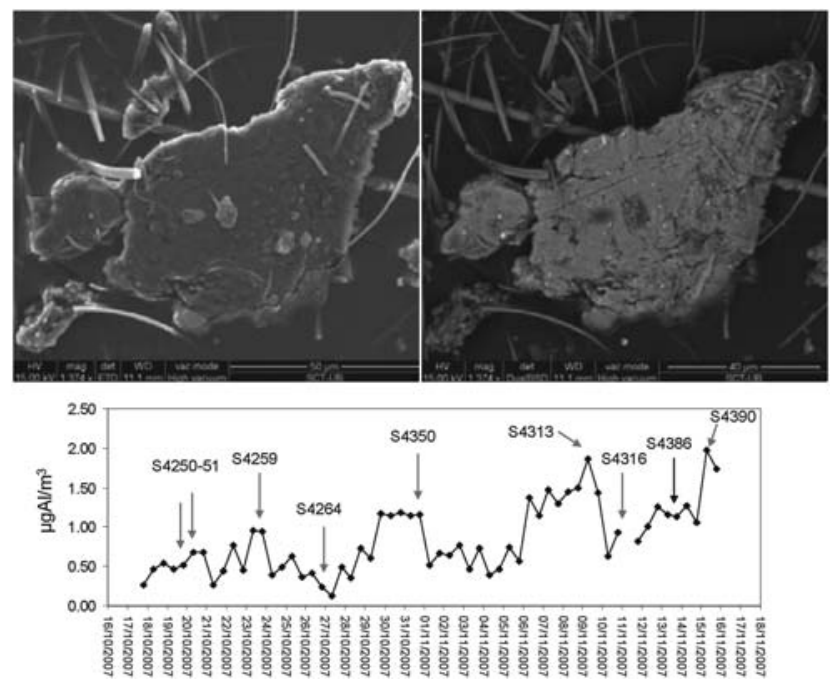

Fig. 9 Top: SEM image (back scattered in the right) of an aluminium alloy flake derived from corroded aircraft fuselage and collected on a $\mathrm{PM}_{10}$ filter of ambient air in El Prat Airport. Brighter points in the right image correspond to $\mathrm{Cu}$-rich areas. Bottom: detected occurrence of aluminium alloy flakes among atmospheric $\mathbf{P M}_{10}$ samples. Arrows indicate wind direction favourable from the runway. 
Al content of the $\mathrm{PM}_{10}$ (Fig. 9). Furthermore, in several cases one could observe not only a positive correlation between the observable presence of $\mathrm{Al}$ airframe flakes and slight increases in total Al content, but also a correspondence between wind directions blowing from the airport runway towards the monitoring site (Fig. 9).

\section{Conclusions}

Ambient concentrations of airborne PM at El Prat Airport during the study period showed values close to a traffic hotspot in Barcelona: $48 \mu \mathrm{g} \mathrm{m}^{-3}$ for $\mathrm{PM}_{10}, 21 \mu \mathrm{g} \mathrm{m}^{-3}$ for $\mathrm{PM}_{2.5}$ and $17 \mu \mathrm{g} \mathrm{m}^{-3}$ for $\mathrm{PM}_{1}$. Daily variations in PM levels are primarily controlled by the alternation of nocturnal land-sourced winds and daytime sea breezes. The night winds channel polluted air from industry and traffic along the Llobregat Valley from the NW, producing $\mathrm{PM}_{10}$ concentrations of $50-60 \mu \mathrm{g} \mathrm{m}^{-3}$ and $\mathrm{PM}_{1} / \mathrm{PM}_{10}$ ratios $>0.5$. The daytime sea breezes advect cleaner marine air across the delta, lowering $\mathrm{PM}_{10}$ concentrations to around $40 \mu \mathrm{g} \mathrm{m}^{-3}$ and raising $\mathrm{PM}_{1} / \mathrm{PM}_{10}$ due to the presence of abundant sea salt. Superimposed upon this meteorological control are the effects of local anthropogenic emissions from the Llobregat delta, the most prominent of which was the effect of dust resuspension during construction works for the new airport terminal.

Chemical data on the $\mathrm{PM}_{10}$ samples indicate that crustal PM are dominant ( $38 \%$ of $\mathrm{PM}_{10}$ ), followed by total C (25\%), SIA $(20 \%)$, and sea salt $(6 \%)$. Source apportionment modelling identifies five factors: industrial/road traffic, crustal, sea salt, SIA, and K likely derived from biomass burning. Our study suggests that on a mean basis most of the bulk PM atmospheric contamination measured around the airport is not attributable directly to aircraft movement, although there are exceptions. The OC concentrations are unusually high for a monitoring site not close to a major road, exceeding a roughly constant $2 \mu \mathrm{g} \mathrm{m}^{-3}$ the simultaneous concentrations registered at urban background. This suggests a possible contribution from aircraft exhaust, especially as these aerosols registered their highest levels when aircraft departures were also at their maximum (Fig. 5). Another suggestion of atmospheric PM contributions sourcing directly from aircraft movements is the drop in $\mathrm{Cu}$ and $\mathrm{Sb}$ ambient air concentrations when landings were at their minimum (Fig. 6), and the unusually high levels specifically of $\mathrm{Ba}, \mathrm{Zn}$ and Mo. We suggest that increases in ambient air levels of these metals may owe their origin at least in part to aerosols released by tyre abrasion and smoke during aircraft landing. However, the regular nocturnal contamination of the Llobregat delta by metalliferous industrial pollution will also contribute to the levels of these metals so that we are unable to quantify the contribution from aircraft tyres. Unequivocal evidence for uniquely aircraftgenerated particles, however, comes from the discovery in the ambient $\mathrm{PM}_{10}$ samples of aluminous microflakes derived from airframe corrosion. These prestressed materials, comprising both pure $\mathrm{Al}$ and alloys of $\mathrm{Al}$ with other metals such as $\mathrm{Cu}$, are characterised by a strongly anisotropic fabric with pancakeshaped metal grains 5-25 $\mu \mathrm{m}$ thick, and they constitute a highly distinctive and unusual type of microparticle. To our knowledge this is the first time flakes of airframe metals have been identified in ambient $\mathrm{PM}_{10}$, but presume that such particles must be commonplace around all airports.

\section{Acknowledgements}

This work was supported by research projects from the Spanish Ministry of Environment (MMA 2006_EG0X2006-M-PARTICULADO-M1) (CALIOPE, 441/2006/3-12.1), the Spanish Ministry of Sciences and Innovation (GRACCIE-CSD200700067, DOASUR CGL2007-62505/CLI) and a fellowship from the Spanish Council of Research (CSIC).

\section{References}

1 DOT, Advisory circular: fuel venting and exhaust emission requirement for turbine engine powered airplanes, Department of Transportation, 2003.

2 EPA, National air quality and emissions trends report, 2003 special studies edition, Research Triangle Park, United States Environmental Protection Agency, 2004, http://www.epa.gov/air/ airtrends.

3 G. P. Brasseur, R. A. Cox, D. Hauglustaine, I. Isaksen, J. Lelieveld, D. H. Lister, R. Sausen, U. Schumann, A. Wahner and P. Wiesen, Atmos. Environ., 1998, 32, 2329-2418.

4 J. Heland and K. Schäfer, Atmos. Environ., 1998, 32, 3067-3072.

5 IPCC, Aviation and the Global Atmosphere. Intergovernmental Panel on Climate Change, Cambridge University Press, 1999.

6 P. J. Popp, G. A. Bishop and D. H. Sedman, Environ. Sci. Technol., 1999, 33, 1542-1544.

7 C. A. Brock, J. Geophys. Res., 2000, 105(D21), 26555-26567.

8 A. S. Kentarchos and G. J. Roelofs, J. Geophys. Res., 2002, 107(13), 8-1-8-12, DOI: 10.1029/2001JD000828.

9 K. Schäfer, C. Jahn, P. Sturm, B. Lechner and M. Bacher, Atmos. Environ., 2003, 37, 5261-5271.

10 K. N. Yu, Y. P. Cheung, T. Cheung and R. C. Henry, Atmos. Environ., 2004, 38, 4501-4507.

11 A. Unal, Y. Hu, M. E. Chang, M. T. Odman and A. G. Russell, Atmos. Environ., 2005, 39, 5787-5798.

12 EPA, Chicago O'Hare Airport Air Toxic Monitoring Program June. Illinois Environmental Protection Agency Bureau of Air, May 2002, http://www.areco.org/IEPA\%20ohare-toxic-report.pdf.

13 S. Hu, S. Fruin, K. Kozawa, S. Mara, A. M. Winer and S. E. Paulson, Environ. Sci. Technol., 2009, 43, 8039-8045.

14 F. Amato, M. Pandolfi, M. Viana, X. Querol, A. Alastuey and T. Moreno, Atmos. Environ., 2009, 43(9), 1650-1659.

15 M. E. Birch and R. A. Cary, Aerosol Sci. Technol., 1996, 25, 221-241.

16 X. Querol, A. Alastuey, S. Rodríguez, F. Plana, E. Mantilla and C. R. Ruiz, Atmos. Environ., 2001, 35, 845-858.

17 L. Han, G. Zhuang, S. Cheng, Y. Wang and J. Li, Atmos. Environ., 2007, 41(35), 7485-7499.

18 K. F. Ho, S. C. Lee, J. C. Chow and J. G. Watson, Atmos. Environ., 2003, 37, 1023-1032.

19 P. Zhao, Y. Feng, T. Zhu and J. Wu, Atmos. Environ., 2006, 40, 58075814.

20 J. C. Chow, J. G. Watson, H. Kuhns, V. Etyemezian, D. H. Lowenthal, D. Crow, S. D. Kohl, J. P. Engelbrecht and M. C. Green, Chemosphere, 2004, 54, 185-208.

21 M. Millán, R. Salvador, E. Mantilla and G. Kallos, J. Geophys. Res., 1997, 102, 8811-8823.

22 N. Perez, J. Pey, X. Querol, A. Alastuey, J. M. Lopez and M. Viana, Atmos. Environ., 2008, 42, 1677-1691.

23 X. Querol, A. Alastuey, T. Moreno, M. Viana, S. Castillo, J. Pey, S. Rodríguez, B. Artiñano, P. Salvador, M. Sánchez, S. Garcia dos Santos, M. C. Herce Garraleta, R. Fernandez-Patier, S. MorenoGrau, L. Negral, M. C. Minguillón, E. Monfort, M. J. Sanz, R. Palomo-Marín, E. Pinilla-Gil, E. Cuevas, J. de la Rosa and A. Sánchez de la Campa, Atmos. Environ., 2008, 42, 3964-3979.

24 X. Querol, M. Viana, A. Alastuey, F. Amato, T. Moreno, S. Castillo, J. Pey, J. de la Rosa, A. Sanchez de la Campa, B. Artıñano, P. Salvador, S. Garcia Dos Santos, R. Fernandez-Patier, S. Moreno-Grau, L. Negral, M. C. Minguillon, E. Monfort, J. I. Gil, A. Inza, L. A. Ortega, J. M. Santamaria and J. Zabalza, Atmos. Environ., 2007, 41, 7219-7231.

25 J. J. Schauer, G. C. Lough, M. M. Shafer, W. F. Christensen, M. F. Arndt, J. T. DeMinter and J.-S. Park, Characterization of Metals Emitted from Motor Vehicles, Health Effect Institute, 2006. 
26 R. C. Henry, C. W. Lewis, P. K. Hopke and H. J. Williamson, Atmos. Environ., 1984, 18, 1507-1515.

27 G. D. Thurston and J. D. Spengler, Atmos. Environ., 1985, 19, 9-25.

28 T. Moreno, F. Amato, X. Querol, A. Alastuey and W. Gibbons, Aust. J. Soil Res., 2008, 46, 128-140.

29 E. Kim and P. K. Hopke, Atmos. Environ., 2008, 42, 6047-6056.

30 F. Amato, M. Pandolfi, A. Escrig, X. Querol, A. Alastuey, J. Pey, N. Perez and P. K. Hopke, Atmos. Environ., 2009, 43, 2770-2780.

31 X. Querol, A. Alastuey, C. R. Ruiz, B. Artiñano, H. C. Hansson, R. M. Harrison, E. Buringh, H. M. ten Brink, M. Lutz, P. Bruckmann, P. Straehl and J. Schneider, Atmos. Environ., 2004, 38, 6547-6555.

32 S. Rodríguez, X. Querol, A. Alastuey, M. Viana, M. Alarcón, E. Mantilla and C. R. Ruiz, Sci. Total Environ., 2004, 328, 95-113.

33 O. P. Ostash, I. M. Andreiko and Y. V. Holovatyuk, Mater. Sci., 2006, 42, 5-16.
34 M. Liao, W. R. Chen and N. C. Bellinger, Int. J. Fatigue, 2008, 30, $717-726$.

35 A. Uebersax, C. Huber, G. Renaud, M. Liao, Structural integrity of a wing skin with exfoliation corrosion, in ICAF 2009, Bridging the Gap between Theory and Operational Practice, ed. M. J. Bos, Springer, Netherlands, 2009, pp. 245-261, DOI: 10.1007/978-90481-2746-7.

36 M. Posada, L. E. Murr, C. S. Niou, D. Roberson, D. Little, R. Arrowood and D. George, Mater. Charact., 1997, 38, 259272.

37 F. Bollenwrath and W. Bungardt, Z. Metall., 1942, 34(7), 160165.

38 A. E. G. Liddiard, J. A. Whittaker and H. K. Farmery, J. Inst. Metals, $1960,89,38-45$

39 R. P. Wei, C. M. Liao and M. Gao, Metall. Mater. Trans. A, 1998, 29, $1153-1160$. 